\title{
U.S. Sulfur Dioxide Emission Reductions: Shifting Factors and a Carbon Dioxide Penalty
}

Marilyn A. Brown, ${ }^{a}{ }^{*}$ Yufei $\mathrm{Li}^{,}{ }^{\mathrm{a}}$ Emanuele Massetti, ${ }^{\mathrm{a}}$ and Melissa Lapsa ${ }^{\mathrm{b}}$

${ }^{a}$ Georgia Institute of Technology, School of Public Policy, 685 Cherry St., Atlanta, GA 30332-0345

${ }^{b}$ Oak Ridge National Laboratory, PO Box 2008, Oak Ridge, TN 37831-6324

December 1, 2016

\section{ABSTRACT}

For more than 20 years, the large-scale application of FGD technology has been a dominant cause of $\mathrm{SO}_{2}$ emission reductions. From 1994-2004, electricity generation from coal increased, but the shift to low-sulfur coal eclipsed this. From 2004-2014, electricity generation from coal decreased, but a shift to higher sulfur subbituminous and lignite coal overshadowed this. The shift in coal quality has also created a $\mathrm{CO}_{2}$ emissions penalty, representing $2 \%$ of the sector's total emissions in 2014.

* Corresponding author, Tel: $00+1+404-385-0303$;

Email address: Marilyn.Brown@pubpolicy.gatech.edu

Key Words:

Sulfur dioxide emission reductions

Carbon dioxide penalty

Decomposition analysis

Electricity generation 


\section{Introduction}

The power sector is responsible for $64 \%$ of the sulfur dioxide $\left(\mathrm{SO}_{2}\right)$ emitted in the United States, damaging human health, ecosystems, crop and timber production, and the built environment. The estimated cost of $\mathrm{SO}_{2}$ pollution from power generation in the United States ranges from \$71 to \$223 billion per year (NRC, 2010; Muller et al., 2011; Muller and Mendelsohn, 2007; Jaramillo and Muller, 2016).

Over the last two decades, $\mathrm{SO}_{2}$ emissions from the U.S. electric power sector have declined sharply, even as electricity generation has increased (Fig. 1). From 1994 to 2004, the focus of this analysis, $\mathrm{SO}_{2}$ emissions decreased by 11.7 million tons/year (a 79\% decline) (EPA, 2016; EIA, 2016a).

The factors contributing to these reductions have evolved over time, and the pace of emission reductions has been variable. Prior research has highlighted the impact of various shifts in market conditions and technologies, highlighting the role of an aging and inefficient coal fleet, the increasingly expensive cost of building new coal plants and rising coal prices, advancements in technology such as FGD pollution controls, the low cost of natural gas and falling costs of renewables, and sluggish electricity demand growth, particularly after the economic downturn of 2008. Policies have also evolved, including the 1990 Clean Air Act Amendments that set limits on $\mathrm{SO}_{2}$ and $\mathrm{NO}_{x}$ gases from power plants, renewable portfolio standards, federal energy efficiency standards on end-use equipment, and much more (e.g., Culver and Hong, 2016; Fleischman, et al., 2013, Tierney, 2012; Chan, et al., 2015).

In this article, we use decomposition analysis to estimate the impact of a range of engineering factors that influence $\mathrm{SO}_{2}$ emissions from the electricity sector and that are driven by these market, policy, and technology shifts. Decomposition analysis has become a commonly accepted method of understanding the factors contributing to carbon emissions since it was first proposed by Kaya (1990) at a workshop of the Intergovernmental Panel on Climate Change (IPCC, 2001). The Kaya identity included three factors: energy intensity, GDP, and population growth. Decomposition analysis has also been used in two recent papers to examine air pollution from Chinese industry. Fujii, Shunsuke, and Kaneko (2013) examined five indicators of 
air pollution from 10 industrial sectors, focusing on end-of-pipe treatment, coal pollution intensity, the energy mix, proactive efficiency, and production scale change. In turn, Yao, et al. (2016), examined three factors impacting air pollution from Chinese industry: engineering emission reduction, structure emission reduction, and supervision emission reduction.

Our analysis is the first application of decomposition analysis to $\mathrm{SO}_{2}$ emissions from the U.S. electricity industry. In particular, we evaluate five factors that have historically impacted $\mathrm{SO}_{2}$ emissions from coal-fired power plants, examining their influence over the past two decades using decomposition analysis. These factors include the amount of electricity generated by coal plants, the sulfur and heat content of the coal burned, the heat rate of electricity generation from coal, and the use of flue gas desulfurization (FGD) pollution controls. We focus on the 1994-2014 period (Fig. 1), and we uncover the dynamics across this period by examining each of the two decades separately.

Fig. 1. 1970-2014 $\mathrm{SO}_{2}$ emissions from electric utilities ${ }^{1}$

(EPA, 2015)

\section{Methodology and data sources}

The attribution of $\mathrm{SO}_{2}$ emissions to different drivers can be evaluated by the following identity:

$$
S O_{2}=G *\left(\frac{S O_{2}}{S}\right) *\left[\left(\frac{S}{\text { Coal }}\right) /\left(\frac{E_{\text {coal }}}{\text { Coal }}\right)\right] *\left(\frac{E_{\text {coal }}}{G}\right) *(1-F G D)
$$

From this identity, the puzzle of $\mathrm{SO}_{2}$ emissions reduction can be solved by illustrating the magnitude and direction of the change precipitated by each factor. Specifically, $\mathrm{SO}_{2}$ emissions are decomposed using the following factors: total power generation (G), the sulfur content of $\operatorname{coal}(\mathrm{S} / \mathrm{Coal})$, the heat content of coal $\left(\mathrm{E}_{\mathrm{coal}} / \mathrm{Coal}\right)$, the heat rate of coal $\left(\mathrm{E}_{\mathrm{coal}} / \mathrm{G}\right)$, and the fraction of emissions after FGD. The identity also includes a combustion factor for sulfur

\footnotetext{
1 Prior to $1994, \mathrm{SO}_{2}$ emissions were estimated rather than aggregated from facility-level reporting. According to Title IV (Acid Deposition Control) of the Clean Air Act Amendments of 1990 (CAAA) published in January 1994, utility units are required to report $\mathrm{SO}_{2}$ data to EPA. Beginning January 1,1995 , all affected units were required to report heat input and $\mathrm{SO}_{2}$ emissions. This change contributed to the "kink" in the curve between 1994 and 1995.
} 
$\left(\mathrm{SO}_{2} / \mathrm{S}\right)$. By assuming that that all sulfur goes into sulfur emissions after combustion, the $\mathrm{SO}_{2} / \mathrm{S}$ value is a constant defined by the relative weight of $\mathrm{SO}_{2}$ to $\mathrm{S}, 1.998 .{ }^{2}$ For each of the factors, we use the natural log of the change in emissions over these two decades to simplify the analysis. $^{3}$

These different components are described in greater detail in Table 1. This decomposition allows for attribution of the change in $\mathrm{SO}_{2}$ emissions to each component driver and the factors contributing most to the decline in $\mathrm{SO}_{2}$ emissions.

\section{Table 1}

Contributing Factors, Units and Data Sources

\section{Contributing factors and trends over the past 20 years}

The five factors can be grouped into three categories: plant performance (generation and heat rate), coal quality (sulfur content and heat content), and emission control (desulfurization technology). Each is described below.

\subsection{Plant performance: electricity generation and heat rate}

While total electricity generation has increased over the past two decades, the electricity generated by coal plants peaked in 2007 , and then declined over the subsequent decade (Figure 2). The overall reduction in coal generation over the two decades declined $7 \%$ from approximately 1700 million MWh in 1994 to 1580 million MWh in 2004.

From 1994 to 2014, total U.S. electricity generation increased while the percent of generation from coal declined slightly. Through 2004 , coal accounted for about $50 \%$ of total U.S. electricity

${ }^{2} \mathrm{SO}_{2} / \mathrm{S}$ is also called the sulfur retention ratio. It is a function of the fraction of sulfur in the coal that ends up in coal ash after combustion and the relative atomic weight of $\mathrm{SO}_{2}$ to $\mathrm{S}$. The former varies from $0 \%$ to about $10 \%$ resulting from the varying composition and quality of coal, along with the operational conditions of plants (Goodarzi, 2006; Sheng et al., 2000).

${ }^{3}$ For example, each factor's contribution over the two decades is calculated as:

$$
\frac{\Delta S}{\ln \left(S_{2014} / S_{1994}\right)} \ln \left(\frac{F_{2014}}{F_{1994}}\right)
$$


generation, but by 2014 , the contribution of electricity generated from coal had declined to $40 \%$. Over this last decade, natural gas and renewables became more prevalent, which has contributed to $\mathrm{SO}_{2}$ emission reductions in the most recent decade.

Fig. 2. Electricity generation from coal and total generation

(Source: EIA, 1995-2015 Table 7.2)

The thermal efficiency of electricity generation is measured by the heat rate, or the amount of thermal energy used to generate one kilowatt-hour of electricity, measured in British thermal units per kilowatt-hour (Btu/kWh). ${ }^{4}$ A generator with a lower heat rate can generate the same quantity of electricity while consuming less fuel, compared to a unit with higher heat rate (EIA, 2015a). Heat rates depend in part on the type of equipment installed at a generating plant and can vary substantially across fuel and technology types. For example, in 2012 generators primarily powered by coal-fired boilers had heat rates ranging from $8,800 \mathrm{Btu} / \mathrm{kWh}$ to 25,000 $\mathrm{Btu} / \mathrm{kWh}$ (EIA, 2015b). A typical heat rate for a coal-fired power plant is around 10,400 $\mathrm{Btu} / \mathrm{kWh}$. The average national heat rate of coal plants has increased by $1.8 \%$ over the past two decades, rising from 10.2 thousand Btu/kWh in 1994 to about 10.4 thousand Btu/kWh in 2014. Thus, coal plants are operating about $2 \%$ less efficiently today compared with 20 years ago, leading to a slight upward pressure on $\mathrm{SO}_{2}$ emissions. This trend is reasonable considering the fact that electricity generation technologies used by coal plants are mature and stable. Other contributors are the implementation of environmental control equipment, existing power plants degradation with relatively few new plants, and the possible shift of load into less efficient coal plants. Since the change in heat rate is relatively small, the driving reasons are difficult to identify.

\subsection{Coal quality: sulfur and heat content}

\footnotetext{
${ }^{4}$ The heat rate is inversely proportional to the thermal efficiency of electricity generation. To express the efficiency of a generator as a percentage, divide the Btu content of a kilowatt-hour of electricity (which is 3,412 $\mathrm{Btu}$ ) by the heat rate. For example, the thermal efficiency of generator with a heat rate of $10,400 \mathrm{Btu} / \mathrm{kWh}$ is equal to $3,412 / 10,400=32.8 \%$.
} 
The quality of coal - including the sulfur content and heat content of coal - varies by geographic region of coal production. In general, coal with a higher sulfur content leads to greater $\mathrm{SO}_{2}$ emissions than coal with a lower sulfur content. The heat content is the amount of thermal energy per unit of coal and is measured in British thermal units per short ton of coal (Btu/ton). Keeping all other factors fixed, a decline in the heat content of coal would result in greater consumption of coal (to produce the same amount of electricity) and greater subsequent $\mathrm{SO}_{2}$ emissions.

Coal plants in 2014 used higher sulfur coal to generate electricity compared to the coal used in 1994, increasing from less than 1.2 to about 1.3 percentage, by weight. However, over these 20 years, sulfur content declined from 1994 to 2002, and then increased fairly consistently from 2003 to 2014.

In contrast, the heat content of coal used in electric utilities has been on a steady, gradual decline over the past 20 years, decreasing from above 20 million Btu/ton coal in 1994 to slightly less than 20 million Btu/ton in 2014. (Fig. 3). Thus, coal plants in 2014 used coal with lower heat content compared to the coal used to generate electricity in 1994.

To better understand these two factors, we need to examine coal quality since these two factors are bundled together when power plants purchase and consume coal. To do this, we introduce the concepts of coal rank and quality. In the United States, the heat content of coal is highest in Anthracite and Bituminous, and is lowest in Subbituminous and Lignite. Anthracite is rare in production and consumption, so the other three types of coal are often referred to as the main coal ranks in North American. In general, specific types of coal can be found concentrated in specific areas. In general, bituminous coal has the highest sulfur content.

- Anthracite - northeastern Pennsylvania;

- Bituminous - east of the Mississippi River, with the greatest amounts in Illinois, Kentucky, and West Virginia;

- Subbituminous coal - west of the Mississippi River, with the greatest amounts in Montana and Wyoming; 
- Lignite - Montana, Texas, and North Dakota.

Fig. 3 describes the level and types of total U.S. coal production in 1994, 2004, and 2014 by region and coal rank. Note that this is the total coal generation from U.S. domestic coal mines, a portion of which is consumed by the electric power sector. Since coal used by the power sector as a percentage of total production was $89 \%$ in $1994,91 \%$ in $2004,92 \%$ in 2014 , it is reasonable to explain the shift using the total generation data available. This figure clearly shows that in the first decade of our analysis period, U.S. coal production shifted from Appalachia bituminous to Western subbituminous. Between 2004 and 2014, the nation experienced an increase in the production of bituminous coal from mines in the Interior region. Appalachia production continued to decrease in this second decade, but less than during the first 10 years, while Western region production decreased slightly.

Fig. 3. Coal production by region, year and coal rank $^{5}$ (Source: EIA, 2016b Table 6)

The shifting of the coal production portfolio used for electric power sector may trigger unintended consequences. As discussed previously, the coal mined in each region (Appalachia, Interior, and Western) not only differ in coal ranks (Bituminous, Subbituminous, Anthracite or Lignite), but also have various quality characteristics. These quality indicators, shown in Table 2 include heat content, sulfur content and emission potentials for mercury, $\mathrm{CO}_{2}$ emission and NOx emissions. These emission potentials per Btu energy input varies significantly. For example, it shows that the mercury emission potential ranges from 4.47 pounds per trillion Btu for Western Bituminous to 14.36 pounds per trillion Btu for Interior Lignite. Nitrogen emission, carbon dioxide potentials also vary between 0.40 pounds per million Btu for Appalachia Bituminous to 0.55 pounds per million for Interior Lignite, 203.10 pounds per million Btu for Interior Bituminous to 219.3 pounds per million Btu for Western Lignite.

\footnotetext{
${ }^{5}$ From 1994 to 2004, U.S. coal production shifted from Appalachia bituminous coal to Western subbituminous coal, contributing to lower overall sulfur content in the coal used for electricity generation. From 2004 to 2013 , production of bituminous coal continued to decline; however, this decline was offset by an increase in the sulfur content bituminous coal (Table 2).
} 


\section{Table 2.}

Qualities of coal by production region and rank Source: EIA (2014); nitrogen oxides estimated using data from EIA (2016c, Table A.2).

Because of this regional shift in coal production, the overall national quality of coal has changed. And the quality of different ranks of coal has shifted as well. Specifically, the sulfur content of bituminous increased from $1.5 \%$ in 2004 to $2.3 \%$ by weight in 2014 , driving the total change from $0.97 \%$ to $1.3 \%$ (Table 3). This rising sulfur content reduced the pace of $\mathrm{SO}_{2}$ emission reductions over the most recent decade.

\section{Table 3.}

National qualities of coal by year and rank Sources: 2004 and 2014 sulfur content of coal in weight data are from EIA (2016c). The other data are author-calculated from data in Table 2 and Figure 3.

While the sulfur content of bituminous coal was increasing, the price of coal was also on the rise. While the cost of coal across all ranks declined from 1994 to 2004, it increased from 2004 to 2014. The high price for bituminous coal may have caused power plants to move to coal with lower sulfur content, which was also cheaper. The Clean Air Act Amendments of 1990 may also have played a role. Such causal relationships $d$ cannot be tested or determined using a decomposition approach.

Fig. 4. The cost of coal consumed in the electric sector (Source: EIA, 2016c, Table 31).

\subsection{Emission Control: Desulfurization Technology and Removal}

The final factor, the use of pollution controls, suggests a strong and obvious change over the past 20 years. The fraction of emissions lacking FGD has declined significantly. FGD is the ratio of emission with flue gas desulfurization to emission without emission control. In other words, it characterizes the proportion of emission left after applying desulfurization technologies. FGD 
dropped from more than $75 \%$ in 1994 to less than $15 \%$ in 2015 . This trend reveals how the application of FGD technology has contributed significantly to the reduction of $\mathrm{SO}_{2}$ emissions.

To explain this trend, we decompose the FGD removal rate using two separate contributing factors: the percent application rate to generation and the removal efficiency of the equipment. Specifically, the formula is as follows:

FGD Removal Ratio = \% of Application Rate to Generation * Removal Efficiency of Equipment.

The FGD application rate to generation experienced a slow uptake prior to 2005 when approximately $30 \%$ of the nation's summer capacity had FGD technology. Subsequently, FGD technology experienced a more rapid decade of expansion. By 2014, FGD technology accounted was installed on $74 \%$ of the summer capacity of U.S. coal plants (EIA, 2016c). ${ }^{6}$

\section{RESULTS: CONTRIBUTION OF EACH FACTOR TO FINAL $\mathrm{SO}_{2}$ REDUCTION}

Using the decomposition methodology and measurements described above, we calculate the changes and contributions of different factors that influenced $\mathrm{SO}_{2}$ emission reductions between 1994, when 14.9 million tons of $\mathrm{SO}_{2}$ were emitted, and 2014, when 3.2 million tons of $\mathrm{SO}_{2}$ were emitted. This 11.7-million-ton reduction in annual emissions is the subject of the decomposition analysis. The results are summarized in Table 3 and are portrayed graphically in Fig.4.

\section{Table 4.}

1994-2014 Changes and Contributions of Different Factors

Fig. 5. Factor contributions: 1994-2004 and 2004-2014

This figure illustrates that three of the contributing factors have had consistent effects on $\mathrm{SO}_{2}$ emissions over time, while two have had directionally different influences across the two decades.

\footnotetext{
${ }^{6}$ Unfortunately, we do not have national data on the removal efficiency of FGD equipment used in the power sector. As a result, we assume that it has not changed over the past two decades.
} 
Flue-gas desulfurization has been responsible for the greatest reduction in $\mathrm{SO}_{2}$ emissions over both decades, accounting for a drop of 4.7 million tons in the first decade and 7.8 million tons in the second decade. The heat content of coal has contributed to small increases in $\mathrm{SO}_{2}$ emissions over both decades, as the overall heat content of coal has decreased. Similarly, the heat rate of coal burning power plants has contributed similarly in both decades to a small uptick in $\mathrm{SO}_{2}$ emissions, as coal plants have aged and the application of FGD technology comes with an energy penalty.

Between 1994 and 2004, coal generation increased, which would have resulted in an uptick of 2 million tons of $\mathrm{SO}_{2}$ emissions, ceteris paribus. Over the same decade, however, the sulfur content of the coal consumed in power plants decreased enough to more than offset the increase in generation. The opposite combination of factors occurred between 2004 and 2014. Coal generation decreased, which would have caused a reduction of 1.3 million tons of $\mathrm{SO}_{2}$ emissions if all other factors had remained the same. Over the same decade, however, the sulfur content of the coal consumed in power plants increased enough to almost offset the decrease in generation.

\section{Impacts on other pollutants}

The shift of the coal production and utilization in the electricity industry from 1994 to 2013 motivated an analysis of the potential influences on the emissions of carbon dioxide, mercury and $\mathrm{NO}_{\mathrm{x}}$. To examine these effects, a hypothetical emission case is calculated assuming that the total energy input (in unit of Btu) remains the same as in 2013 , but the production portfolio accords to the 1994 level without any coal production shifts. The intention of this mechanisms is to rule out the total energy input differences from the year 1994 and 2013, and only examine the coal shift as an influence on emissions. The results are shown in Table 5, illustrating the directions and magnitudes of the "unintended consequences" on these other pollutants. In particular, the coal shift is responsible for an additional 41 million short tons of $\mathrm{CO}_{2}$ emissions in 2014 relative to the coal composition in 2004, representing $2 \%$ of the sector's $\mathrm{CO}_{2}$ emissions from U.S. electric power in 2014.

\section{Table 5.}


Impact of shifting sources of coal on $\mathrm{CO}_{2}$ emissions (in million tons of carbon dioxide)

Based on the Reference Case Forecast of coal production using Georgia Tech's National Energy Modeling System (GT-NEMS), the trend toward greater use of high-sulfur coal will continue through 2030, suggesting that the unanticipated carbon dioxide penalty could continue (Figure 6). If the Clean Power Plan were implemented with mass-based caps on state $\mathrm{CO}_{2}$ emissions covering all affected electricity generating units, the trend toward high-carbon coal would be moderated, as bituminous Appalachian coal with relatively low carbon content retains more of its market share through 2030.

Fig. 6. Coal Production Projections by Region

\section{Conclusions}

From 1994 to 2014 , annual $\mathrm{SO}_{2}$ emissions from electric utilities decreased by 11.7 million tons, a $79 \%$ decline. During this period of historic improvement in air quality, both the pace of improvement and the factors contributing to $\mathrm{SO}_{2}$ emissions reduction have varied.

Across the 20-year period, the massive application of FGD technology was the most significant cause of $\mathrm{SO}_{2}$ emission reductions from the electricity sector. Changing levels of electricity generation from coal plants to cleaner alternatives and shifts in the sulfur content of the coal consumed by these plants were the next most influential factors, and their impacts were different and countervailing over the past 20 years. The large-scale application of FGD technology since 1994 has obscured these smaller underlying trends, especially the decreasing quality of coal being combusted to produce electricity, both in terms of its increasing sulfur content and its decreasing heat rate.

- From 1994 to 2014 , the one factor that has consistently been the biggest contributor to reductions in $\mathrm{SO}_{2}$ emissions is the installations of $\mathrm{FGD}$ controls, which were installed to comply with environmental regulations.

- From 1994 to 2004, the second biggest driver was the reduced sulfur content of the coal burned at power plants in the United States. Between 1994 and 2004, coal generation increased, which would have resulted in an uptick of 2 million tons of $\mathrm{SO}_{2}$ emissions if 
no other changes had occurred. Over the same decade, however, the sulfur content of the coal consumed in power plants decreased enough to more than offset the increase in generation.

- From 2004 to 2014, the opposite combination of factors occurred. Coal generation decreased as a result of the greater use of natural gas and renewables, which would have caused a reduction of 1.3 million tons of $\mathrm{SO}_{2}$ emissions in the absence of other changes. Over the same decade, however, the sulfur content of the coal consumed in power plants increased enough to almost offset the decrease in generation.

This shift in coal sources was also responsible for an estimated increase of 41 million tons of $\mathrm{CO}_{2}$ emissions from the electric power sector in 2014 representing $2 \%$ of the sector's total and a trend that is expected to continue in the absence of the Clean Power Plan.

\section{References}

Chan, H.R., Chupp B.A., Cropper, M., Muller N. 2015. The Net Benefits of the Acid Rain Program: What Can We learn from the Grand Policy Experiment? Resources for the Future.

Culver, W. J., \& Hong, M. 2016. Coal's decline: Driven by policy or technology? The Electricity Journal, 29(7), 50-61. doi:http://dx.doi.org/10.1016/j.tej.2016.08.008

Energy Information Administration. 2016a. Monthly Energy Review. 2016: Table 7.2b Electricity Net Generation: Electric Power Sector: http://www.eia.gov/totalenergy/data/monthly/. Accessed April 7, 2016.

Energy Information Administration. 2016b. Annual Coal Report 2014, Table 6, http://www.eia.gov/coal/annual/pdf/acr.pdf. Accessed January 14, 2016

Energy Information Administration. 2016c. Electric Power Annual. Tables 9.2 and A.2, http://www.eia.gov/electricity/annual/. Accessed March 14, 2016.

Energy Information Administration. 2015a. What is the efficiency of different types of power plants? http://www.eia.gov/tools/faqs/faq.cfm?id=107\&t=3. Accessed January 19, 2016. 
Energy Information Administration. 2015b. Analysis of Heat Rate Improvement Potential at Coal-Fired Power Plants. p. 1. http://www.eia.gov/analysis/studies/powerplants/heatrate/. Accessed January 21, 2016.

Energy Information Administration. 2014. Coal Market Module of the National Energy Modeling System 2014, DOE/EIA-M060 (2014) (Washington, DC).

Environmental Protection Agency. 2016. Air Pollutant Emissions Trends Data, 1970-2014: https://www.epa.gov/air-emissions-inventories/air-pollutant-emissions-trends-data. Accessed April 7, 2016.

Environmental Protection Agency, National Emissions Inventory (NEI). 2015. https://www.epa.gov/air-emissions-inventories/air-pollutant-emissions-trends-data, Accessed January 142016.

Fleischman, L., Cleetus, R., Deyette, J., Clemmer, S., \& Frenkel, S. 2013. Ripe for Retirement: An Economic Analysis of the U.S. Coal Fleet. The Electricity Journal, 26(10), 51-63. doi:http://dx.doi.org/10.1016/j.tej.2013.11.005

Fujii, H., Shunsuke, M. Kaneko, S. 2013. Decomposition analysis of air pollution abatement in China: empirical study for ten industrial sectors from 1998 to 2009. Journal of Cleaner Production 59: 22-31.

Goodarzi, F. 2006. Assessment of elemental content of milled coal, combustion residues, and stack emitted materials: possible environmental effects for a Canadian pulverized coalfired power plant. International Journal of Coal Geology. 65(1): 17-25.

Intergovernmental Panel for Climate Change. 2001. Summary for policymakers: a report of Working Group I of the Intergovernmental Panel on Climate Change. Climate change, 120: Section 3.1. http://www.ipcc.ch/ipccreports/sres/emission/index.php?idp=0, Accessed in March 14, 2016. 
Jaramillo, P., Muller, N.Z. 2016. Air pollution emissions and damages from energy production in the US: 2002-2011. Energy Policy 90, 202-211, Table 1, page 206.

\section{http://www.sciencedirect.com/science/article/pii/S0301421515302494}

Kaya, Y. 1990. Impact of carbon dioxide emission control on GNP growth: Interpretation of proposed scenarios. Paper presented at the IPCC Energy and Industry Subgroup, Response Strategies Working Group, Paris, France.

Muller, N.Z., Mendelsohn, R. 2007. Measuring the damages of air pollution in the United States. Journal of Environmental Economics and Management. 54(1), 1-14. http://dx.doi.org/10.1016/j.jeem.2006.12.002.

Muller, N.Z., Mendelsohn, R, Nordhaus, W. 2011. Environmental accounting for pollution in the United States economy. The American Economic Review. 1649-1675. Table 5, p. 1670. http://www.jstor.org/stable/23045618

National Research Council (NRC). Committee on Health, Environmental, Other External Costs, Benefits of Energy Production, and Consumption. 2010. Hidden costs of energy: unpriced consequences of energy production and use. National Academies Press. Page 92. http://www.nap.edu/login.php?record id=12794\&page=http\%3A\%2F\%2Fwww.nap.edu \%2Fdownload.php\%3Frecord id\%3D12794

Sheng, C. et al. 2000. Comparison of sulphur retention by coal ash in different types of combustors." Fuel Processing Technology. 64(1): 1-11.

Tierney, Sue, 2012. Why Coal Plants Retire: Power Market Fundamentals as of 2012, Analysis Group Inc.

Yao, L., Liu, J., Zhou, T, Wang, R. 2016. An analysis of the driving forces behind pollutant mission reduction in Chinese industry. Journal of Cleaner Production 112: 1395-1400. 


\section{Table 1}

Contributing Factors, Units and Data Sources

\begin{tabular}{|c|c|c|c|}
\hline Factor & Explanation & Unit & Source \\
\hline G & $\begin{array}{l}\text { Total Generation from } \\
\text { Coal Plants }\end{array}$ & MWh & $\begin{array}{l}\text { EIA Monthly Energy Review } \\
\text { http://www.eia.gov/totalenergy/data/monthly/ }\end{array}$ \\
\hline S/Coal & $\begin{array}{l}\text { Sulfur Content of Coal } \\
\text { Used }\end{array}$ & $\begin{array}{l}\% \text { in } \\
\text { Weight }\end{array}$ & $\begin{array}{l}\text { EIA-923 Survey, } \\
\text { https://www.eia.gov/electricity/data/eia923/ }\end{array}$ \\
\hline$E_{\text {coal }} /$ Coal & $\begin{array}{l}\text { Heat Content of Coal } \\
\text { used }\end{array}$ & $\begin{array}{l}\text { Btu/tons } \\
\text { coal }\end{array}$ & $\begin{array}{l}\text { EIA-923 Survey, } \\
\text { https://www.eia.gov/electricity/data/eia923/ }\end{array}$ \\
\hline$E_{\text {coal }} / \mathrm{G}$ & $\begin{array}{l}\text { Heat Rate of Coal } \\
\text { Plants }\end{array}$ & $\begin{array}{l}\text { Btu/tons } \\
\text { coal }\end{array}$ & $\begin{array}{l}\text { EIA Monthly Energy Review } \\
\text { http://www.eigov/totalenergy/data/monthly/ }\end{array}$ \\
\hline & Fraction of Emissions & & $\begin{array}{l}\text { Form EIA-860 Annual Electric Generator Report, } \\
\underline{\text { https://www.eia.gov/electricity/data/eia860/ }}\end{array}$ \\
\hline FGD & $\begin{array}{l}\text { Lacking Flue Gas } \\
\text { Desulfurization }\end{array}$ & $\%$ & $\begin{array}{l}\text { Calculated from variables above as well as annual } \mathrm{SO}_{2} \\
\text { emissions from EPA (2015) and validated by data from } \\
\text { EIA (2016c) }\end{array}$ \\
\hline
\end{tabular}

\section{Table 2.}

Qualities of coal by production region and rank

\begin{tabular}{lcccccc}
\hline Region & $\begin{array}{c}\text { Coal } \\
\text { Rank }\end{array}$ & $\begin{array}{c}\text { Heat Content } \\
\text { (million Btu } \\
\text { per short ton) }\end{array}$ & $\begin{array}{c}\text { Sulfur } \\
\text { Content } \\
\text { (pounds per } \\
\text { million Btu) }\end{array}$ & $\begin{array}{c}\text { Mercury } \\
\text { Content } \\
\text { (pounds per } \\
\text { trillion Btu) }\end{array}$ & $\begin{array}{c}\text { CO } \text { (pounds } \\
\text { per million } \\
\text { Btu) }\end{array}$ & $\begin{array}{c}\text { NO } \text { (pounds } \\
\text { per million } \\
\text { Btu) }\end{array}$ \\
\hline Appalachia & BIT & 24.73 & 1.74 & 9.86 & 205.36 & 0.40 \\
Interior & BIT & 22.61 & 2.60 & 6.49 & 203.10 & 0.44 \\
& LIG & 13.01 & 1.55 & 14.36 & 212.86 & 0.55 \\
& BIT & 21.65 & 0.53 & 4.47 & 209.89 & 0.46 \\
& LIG & 13.23 & 1.24 & 8.38 & 219.30 & 0.54 \\
& SUB & 17.53 & 0.37 & 5.76 & 214.55 & 0.42
\end{tabular}

Source: EIA (2014); nitrogen oxides estimated using data from EIA (2016c, Table A.2). 


\section{Table 3.}

National qualities of coal by year and rank

\begin{tabular}{|c|c|c|c|c|c|c|c|c|}
\hline Year & $\begin{array}{l}\text { Coal } \\
\text { Rank }\end{array}$ & $\begin{array}{c}\text { Heat } \\
\text { Content } \\
\text { (million } \\
\text { Btu per } \\
\text { short ton) }\end{array}$ & $\begin{array}{l}\text { Sulfur } \\
\text { Content } \\
\text { (pounds } \\
\text { per } \\
\text { million } \\
\text { Btu) }\end{array}$ & $\begin{array}{c}\text { Mercury } \\
\text { Content } \\
\text { (pounds } \\
\text { per trillion } \\
\text { Btu) }\end{array}$ & $\begin{array}{c}\mathrm{CO}_{2} \\
\text { (pounds } \\
\text { per } \\
\text { million } \\
\text { Btu) }\end{array}$ & $\begin{array}{c}\mathrm{NO}_{2} \\
\text { (pounds } \\
\text { per million } \\
\text { Btu) }\end{array}$ & $\begin{array}{l}\text { Sulfur } \\
\text { in } \\
\text { Weight } \\
\%\end{array}$ & $\begin{array}{c}\text { Sulfur in } \\
\text { Weight \% } \\
\text { (National } \\
\text { Avg by } \\
\text { Energy } \\
\text { Contents of } \\
\text { Production) }\end{array}$ \\
\hline \multirow{3}{*}{1994} & BIT & 24.0 & 1.8 & 8.7 & 205.4 & 0.4 & 2.1 & \multirow{3}{*}{1.17} \\
\hline & SUB & 17.5 & 0.4 & 5.8 & 214.5 & 0.4 & 0.3 & \\
\hline & LIG & 13.0 & 1.5 & 14.4 & 212.9 & 0.5 & 1.0 & \\
\hline \multirow{3}{*}{2004} & BIT & 24.0 & 1.7 & 8.6 & 205.6 & 0.4 & 1.5 & \multirow{3}{*}{0.97} \\
\hline & SUB & 17.5 & 0.4 & 5.8 & 214.5 & 0.4 & 0.4 & \\
\hline & LIG & 13.1 & 1.4 & 12.2 & 215.2 & 0.5 & 1.1 & \\
\hline 2014 & BIT & 23.7 & 1.8 & 8.2 & 205.3 & 0.4 & 2.3 & 1.3 \\
\hline
\end{tabular}

Sources: 2004 and 2014 sulfur content of coal in weight data are from EIA (2016c). The other data are author-calculated from data in Table 2 and Figure 3. 
Table 4.

1994-2014 Changes and Contributions of Different Factors

\begin{tabular}{|c|c|c|c|c|c|c|}
\hline & $\begin{array}{c}\text { Emission } \\
\text { (Thousand } \\
\text { Tons) }\end{array}$ & S/Coal (\%) & $\begin{array}{c}\text { E/Coal } \\
\text { (million } \\
\text { Btu/ton) }\end{array}$ & $\begin{array}{c}\text { E/G } \\
\text { (Thousand } \\
\text { Btu/kWh) }\end{array}$ & $\begin{array}{l}\text { G (million } \\
\text { MWh) }\end{array}$ & FGD (\%) \\
\hline 1994 & 14,889 & 1.17 & 20.59 & 10.21 & 1691 & 75.9 \\
\hline 2004 & 10249 & 0.97 & 19.94 & 10.26 & 1978 & 52.0 \\
\hline 2014 & 3,195 & 1.3 & 19.31 & 10.39 & 1582 & 14.4 \\
\hline \multicolumn{7}{|l|}{$1994-2014$} \\
\hline Difference & $-11,694$ & 0.13 & -1.28 & 0.19 & -109 & -61.5 \\
\hline Change & $-79 \%$ & $11 \%$ & $-6 \%$ & $2 \%$ & $-6 \%$ & $-81 \%$ \\
\hline $\begin{array}{l}\text { Single factor Contributions } \\
\text { (thousand tons } \mathrm{SO}_{2} \text { emission) }\end{array}$ & & 801 & 489 & 137 & -506 & -12614 \\
\hline \multicolumn{7}{|l|}{ 1994-2004 } \\
\hline Difference & $-4,640$ & -0.20 & -0.65 & 0.05 & 287 & -23.9 \\
\hline Change & $-31 \%$ & $-17 \%$ & $-3.2 \%$ & $0.5 \%$ & $17 \%$ & $-32 \%$ \\
\hline $\begin{array}{l}\text { Single factor Contributions } \\
\text { (thousand tons } \mathrm{SO}_{2} \text { emission) }\end{array}$ & & -2329 & 398 & 66 & 1952 & -4701 \\
\hline \multicolumn{7}{|l|}{ 2004-2014 } \\
\hline Difference & $-7,054$ & 0.33 & -0.63 & 0.13 & -396 & -37.6 \\
\hline Change & $-69 \%$ & $34 \%$ & $-3.2 \%$ & $1.3 \%$ & $-20 \%$ & $-72 \%$ \\
\hline $\begin{array}{l}\text { Single factor Contributions } \\
\text { (thousand tons } \mathrm{SO}_{2} \text { emission) }\end{array}$ & & 1772 & 196 & 77 & -1354 & -7757 \\
\hline
\end{tabular}




\section{Table 5.}

Impact of shifting sources of coal on $\mathrm{CO}_{2}$ emissions (in million tons of carbon dioxide)

\begin{tabular}{|c|c|c|c|c|c|c|c|}
\hline & $\begin{array}{c}\text { Appalachia- } \\
\text { BIT }\end{array}$ & $\begin{array}{l}\text { Interior- } \\
\text { BIT }\end{array}$ & $\begin{array}{l}\text { Interior- } \\
\text { LIG }\end{array}$ & Western-BIT & Western-LIG & $\begin{array}{l}\text { Western- } \\
\text { SUB }\end{array}$ & $\begin{array}{c}\text { Total } \\
\text { (\% of electric } \\
\text { sector emissions) }\end{array}$ \\
\hline 1994 & 1119.6 & 284.7 & 45.7 & 170.4 & 0.0 & 565.9 & 2186.2 \\
\hline 2004 & 985.6 & 213.1 & 73.7 & 180.6 & 44.0 & 874.9 & 2371.9 \\
\hline 2013 & 680.4 & 307.6 & 67.9 & 154.5 & 40.6 & 815.9 & 2066.9 \\
\hline $\begin{array}{r}2013 \text { Energy Input } \\
\text { with } 1994 \text { Coal Mix }\end{array}$ & 1050.8 & 267.2 & 42.9 & 159.9 & 0.0 & 531.1 & 2051.8 \\
\hline $\begin{array}{r}\% \text { Change from } 2013 \\
\text { Real Emissions }\end{array}$ & -0.5 & 0.1 & 0.4 & 0.0 & 1.0 & 0.3 & $15(0.7 \%)$ \\
\hline $\begin{array}{r}2013 \text { Energy Input } \\
\text { with } 2004 \text { Coal Mix }\end{array}$ & 810.8 & 180.4 & 63.0 & 165.7 & 43.3 & 762.4 & 2025.7 \\
\hline $\begin{array}{r}\% \text { Change from } 2013 \\
\text { Real Emissions }\end{array}$ & -0.2 & 0.4 & 0.1 & -0.1 & -0.1 & 0.1 & $41(2.0 \%)$ \\
\hline
\end{tabular}




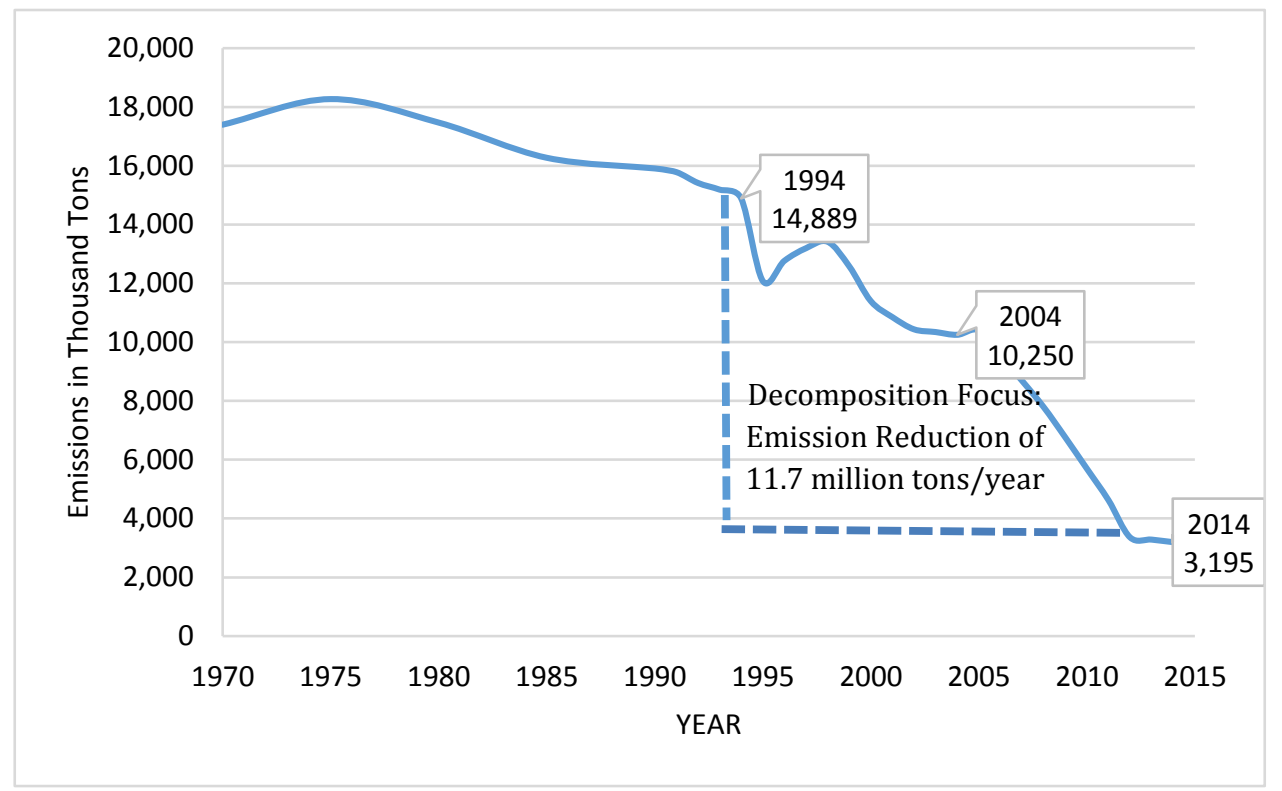

Fig. 1. 1970-2014 $\mathrm{SO}_{2}$ emissions from electric utilities

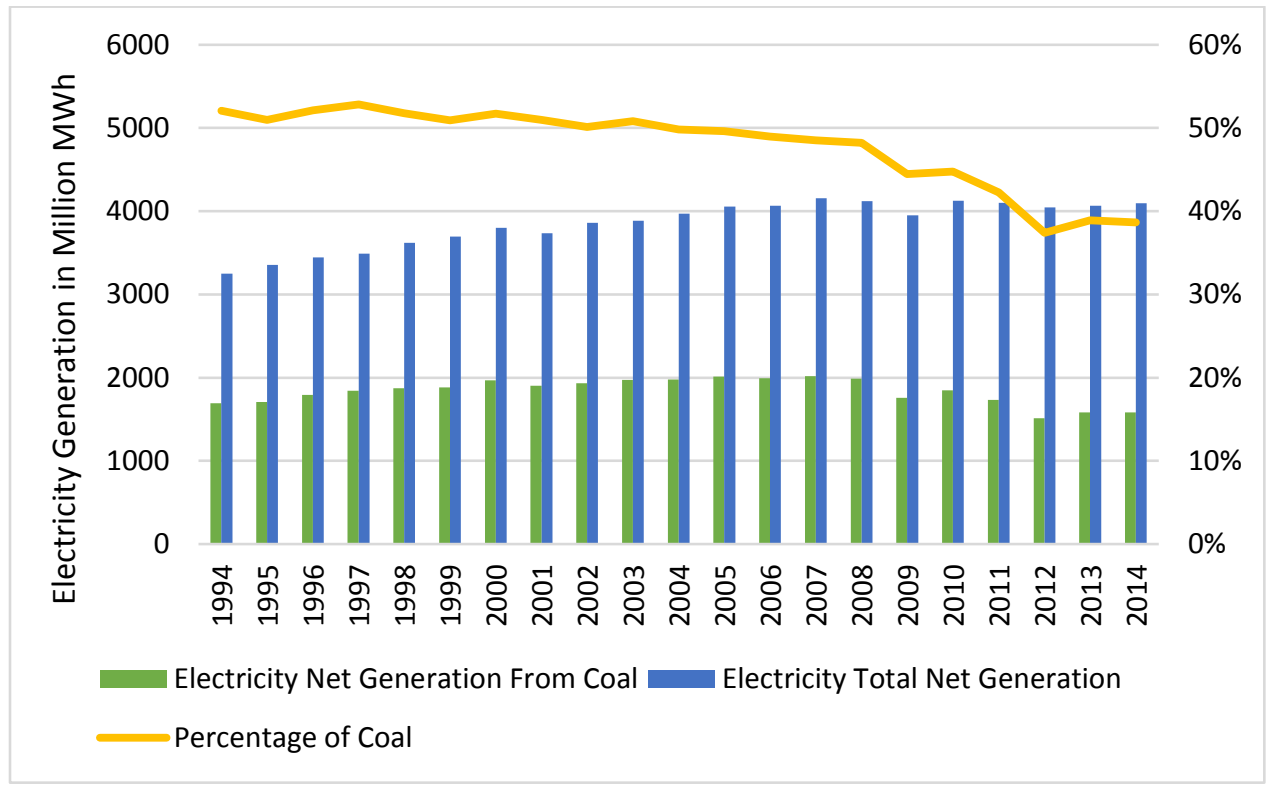

Fig. 2. Electricity generation from coal and total generation

(Source: EIA, 1995-2015 Table 7.2) 


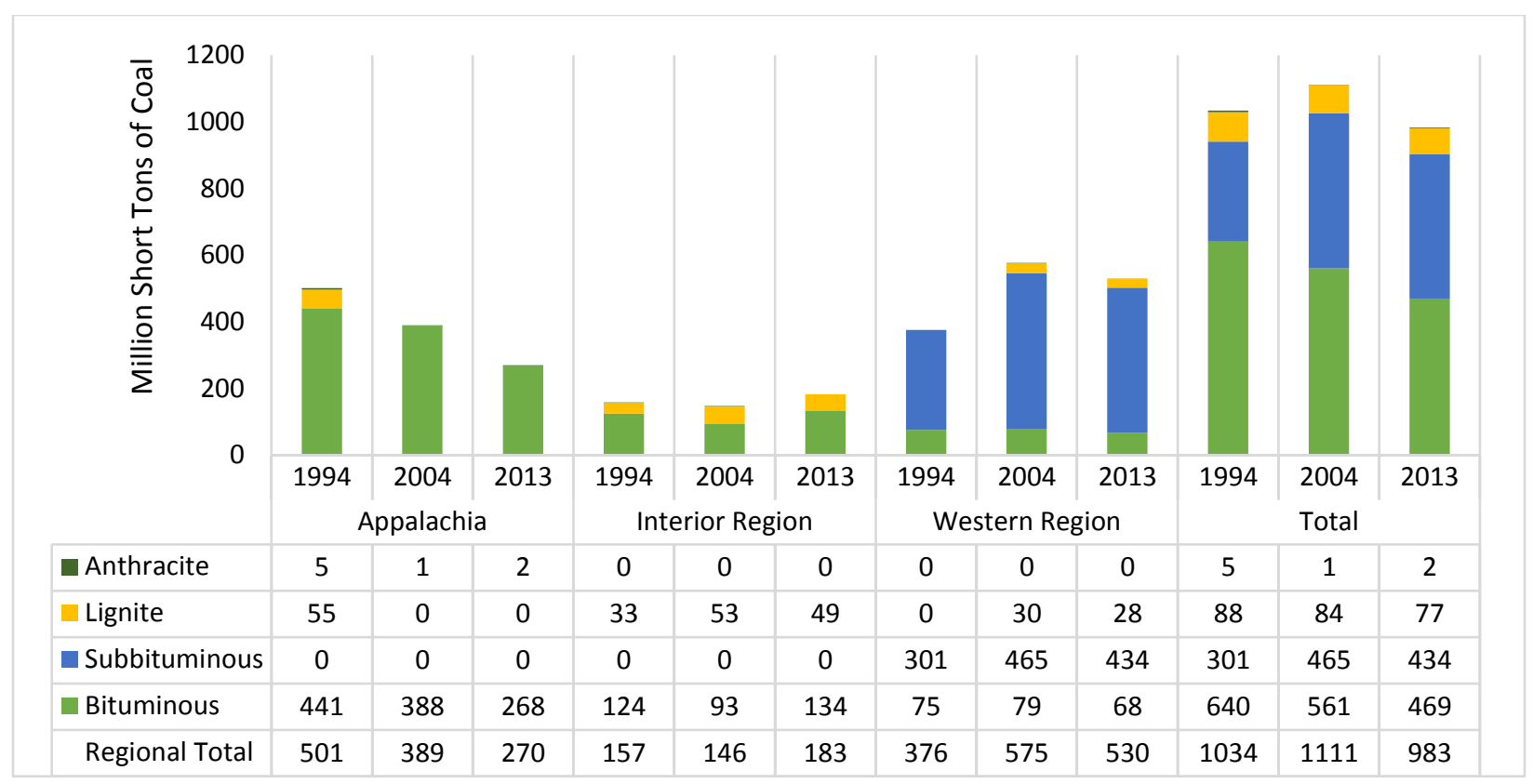

Fig. 3. Coal production by region, year and coal rank ${ }^{1}$

(Source: EIA, 2016b Table 6)

\footnotetext{
${ }^{1}$ From 1994 to 2004, U.S. coal production shifted from Appalachia bituminous coal to Western subbituminous coal, contributing to lower overall sulfur content in the coal used for electricity generation. From 2004 to 2013 , production of bituminous coal continued to decline; however, this decline was offset by an increase in the sulfur content bituminous coal (Table 2).
} 


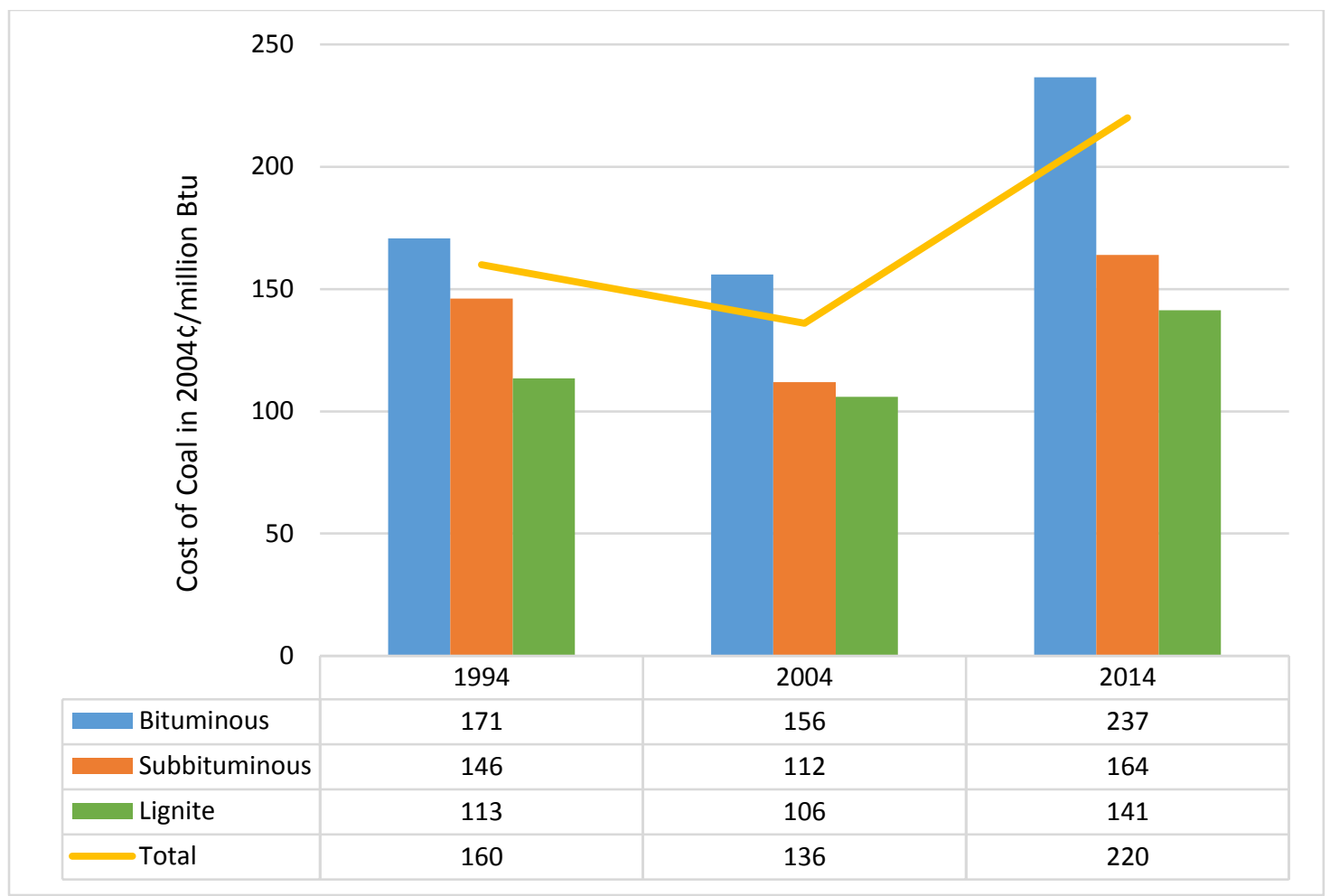

Fig. 4. The cost of coal consumed in the electric sector

(Source: EIA, 2016c, Table 31). 


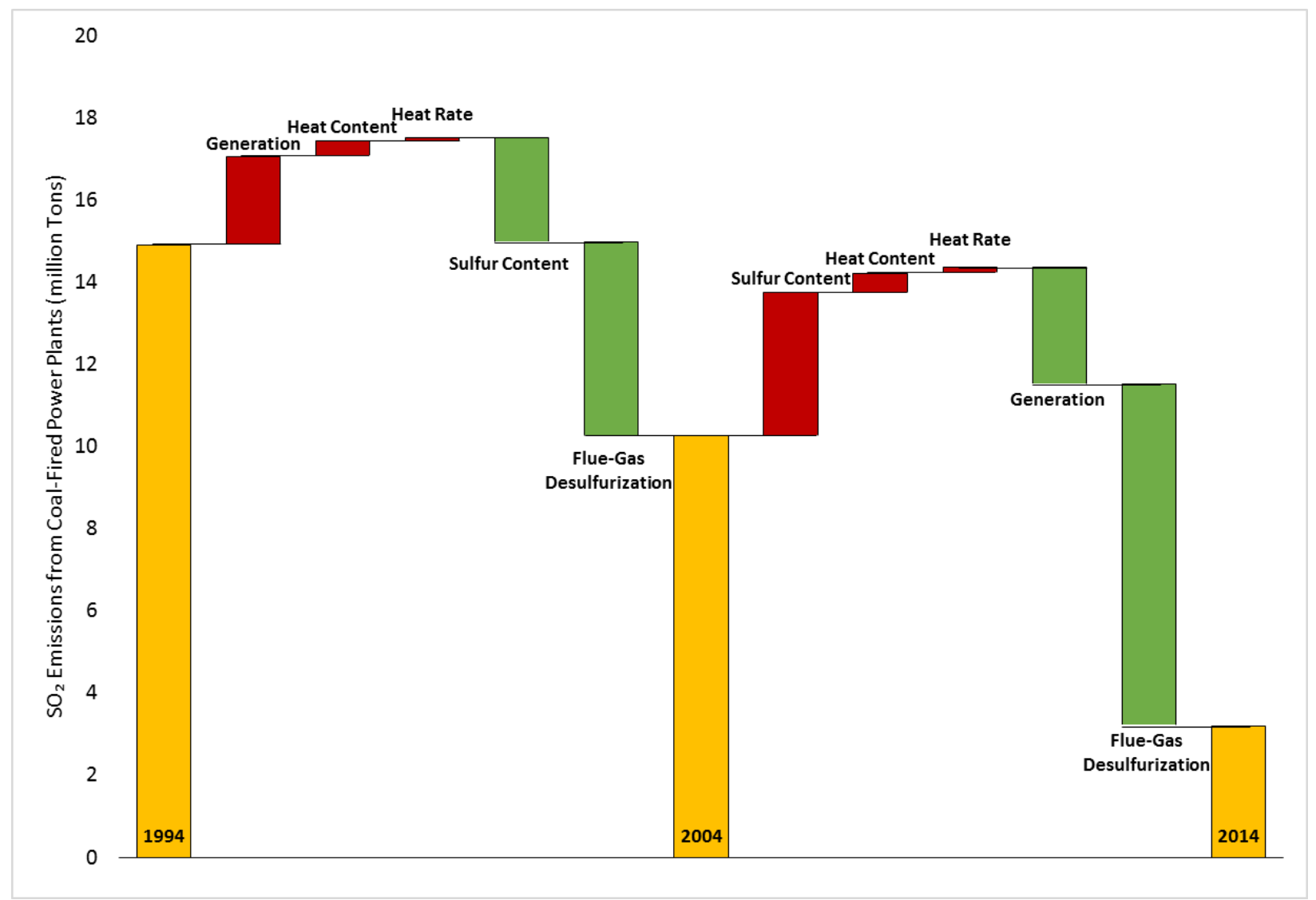

Fig. 5. Factor contributions: 1994-2004 and 2004-2014



Fig. 6. Coal Production Projections by Region 